Annales Missiologici Posnanienses t. 23 (2018), s. 165-175

doi: 10.14746/amp.2018.23.11

JUSTYNA SPRUTTA

Uniwersytet im. Adama Mickiewicza w Poznaniu

Wydział Teologiczny

\title{
Misyjny wymiar ikony Zestanie Ducha Świętego
}

Każda ikona, jako specyficzna przestrzeń uobecnienia się i emanacji sacrum, zawiera misyjne przesłanie. Jednak ikona Zesłanie Ducha Świętego (z rzędu ikon świąt [Dodekaorton] w ikonostasach) wprost wyraża tę ideę, niejako bez ram czasowo-przestrzennych.

\section{Idea misyjnego posłania}

Ikonografia zesłania Ducha Świętego (Dz 2,1-13) krystalizuje się pomiędzy VI i XI w. Za najstarsze przedstawienie tego misterium uchodzi, pochodząca z 586 r., miniatura z syryjskiego Kodeksu Rabbuli (ilustracja 1: dalej il.). Na około 600 r. datowane są natomiast ampułki z Monzy, z Pięćdziesiątnica jako jednym z tematów, zwłaszcza ampułka numer 10 (por. Іванчо 393-394; Bulas 94; Passarelli 286). Wspomniana miniatura z Kodeksu Rabbuli ukazuje Ducha Świętego (gołębicę i płomienie), Matkę Bożą (Oranta) i apostołów, ale nie jest to jeszcze prototyp przedstawienia znanego z klasycznych, ilustrujących Pięćdziesiątnicę ikon. Nie mamy też tutaj wyraźnie zaznaczonej idei misyjnego posłania, mimo iż istnieje ona $\mathrm{w}$ domyśle. Nieobecny jest na tej miniaturze adresat owej apostolskiej misji, realizowanej przez Kościół i w Kościele, którego zresztą żywotność „wyraża się w sposób naturalny w jego ekspansji misyjnej" (Evdokimov, Prawosławie 177) oraz którego obraz i model prezentuje ikona Zesłanie Ducha Świętego (Evdokimov, Prawosławie 177). Ponadto to Duch Święty usprawnia misyjnie Kościół, który „w swojej tajemnicy sakramentalnej i liturgicznej staje się przeciwieństwem wszelkiego statycznego ontologizmu instytucjonalnego: ożywiające energie Ducha Świętego czynią go wydarzeniem w istocie swej dynamicznym" (Evdokimov, Duch Święty w tradycji prawosławnej 136). Właśnie w Kościele Duch Święty aktualizuje i kon- 


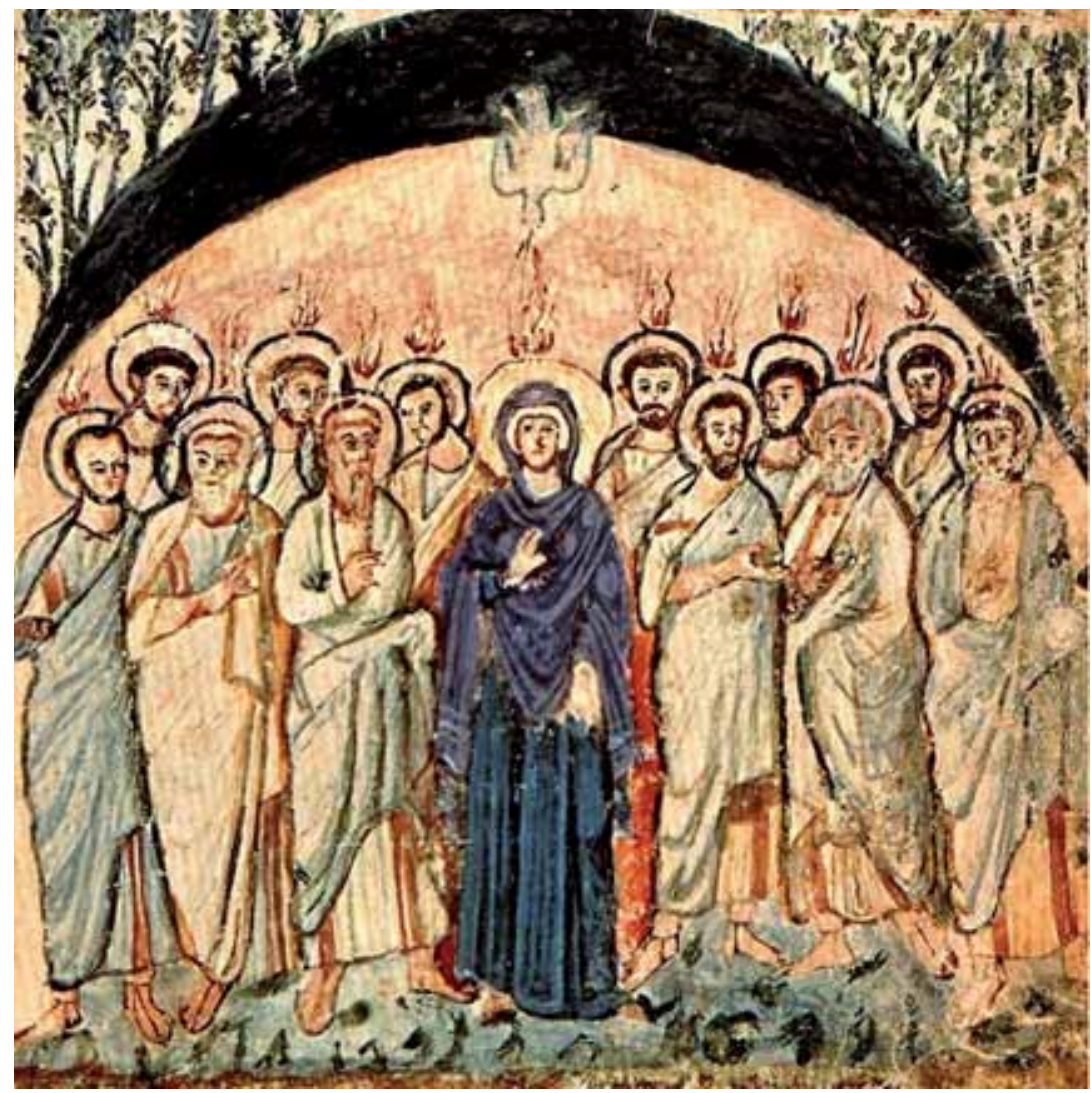

Ilustracja 1. Miniatura z Kodeksu Rabbuli: Dostęp 25 sierpnia 2018. <http://posztukiwania.pl/wp-content/uploads/2018/03/800px-RabulaGospelsFolio14vPentecost.jpg>

kretyzuje dzieło Jezusa Chrystusa w świecie, a pięćdziesiątnica w tym kontekście jawi się, według metropolity Sawy, jako „ten akt Boży, który wynosi paschalne misterium Chrystusa w sferę wiecznie trwającego 'teraz'. Wszystko [bowiem - J.S.], czego dokonuje Duch Święty wiąże się z wiecznie trwającym misterium Paschy Chrystusowej” (Metropolita Sawa i Baczyński 389). Duch Święty-Paraklet i zarazem Mądrość Boża jednoczy Kościół, a Jego obecność, symbolizowana przez rozdzielone i spoczywające oddzielnie na apostołach (w tym także na Matce Bożej) płomienie, wskazuje na różnorodność w Kościele (Leśniewski 119-120; o ikonografii Ducha Świętego: por. Cyrek 61)

${ }^{1}$ Następująco wypowiada się Serafin z Sarowa o napełnieniu apostołów Duchem Świętym: „I w dniu Pięćdziesiątnicy uroczyście zesłał Ducha Świętego, który w szumie wiatru i pod posta- 
Istotne miejsce zarówno w Kościele, jak i w ikonografii zesłania Ducha Świętego zajmują apostołowie. Wypracowany do XI w. wariant przedstawienia tego misterium ukazuje Dwunastu już nie jako stojących (por. miniatura z Kodeksu Rabbuli), ale jako zasiadających w półokręgu na synthrononie (Bator 248)². Wśród nich znajdują się także postacie niebędące apostołami: Paweł, zwany wcześniej Szawłem, oraz ewangeliści Marek i Łukasz (Kiejkowski 193) ${ }^{3}$. Za Piotrem i Pawłem, którzy flankują puste, przeznaczone dla Mesjasza miejsce ${ }^{4}$, widnieją ewangeliści: Mateusz i Marek oraz Jan i Łukasz. Zdarza się też, że ewangeliści, wraz z Pawłem, dzierżą księgi symbolizujące objawioną doktrynę, a pozostali - zwoje jako symbol nauczania (Janocha, Ukraińskie i białoruskie ikony... 404). Centralne, również na ikonie, usytuowanie Piotra i Pawła uwydatnia pełnię (ros. sobornost') Chrystusowego Kościoła (por. Janocha, Ukraińskie i białoruskie ikony... 404). Ponadto na owej ikonie przenikają się dwie prawdy, tworząc jedną rzeczywistość: Ewangelia nie została jeszcze spisana, ale poniekąd jest już zapisana, czego niejako dowodzi obecność ewangelistów, a o czym mówią nam m.in. ich atrybuty i jej adresat. Apostołowie wyobrażani są w sali Wieczernika lub na zewnątrz. O tym, że akcja rozgrywa się we wnętrzu, świadczy ściana łącząca dwie wieże lub pełniące tę samą funkcję czerwone velum. Owe wieże można interpretować, co zresztą sugeruje Paweł Kiejkowski, jako symboliczną wizję Kościoła (Kiejkowski 193).

Po bizantyńskim ikonoklazmie (IX w.) zanika obecność Matki Bożej w apostolskim gronie, ustępując przed pustką. Puste miejsce przeznaczone zostaje dla przychodzącego powtórnie Zbawiciela, jednakże w okresie nowożytnym, pod wpływem okcydentalizacji m.in. ikon, Maryja pojawia się ponownie i często, we wschodniej ikonografii Pięćdziesiątnicy (sporadycznie widnieje już np. na ikonach z XIII w.), a samo symboliczne przedstawienie tego wydarzenia przekształca się w scenę historyczną (Janocha, Ikony w Polsce 220; Janocha, Ukrainskie i białoruskie ikony... 404; por. Passarelli 286; Smykow-

cią języków ognia zstąpił na każdego z Apostołów i wstąpił w nich, napełnił ich mocą podobnej do ognia łaski Bożej, dyszącej rosiście i radośnie działającej w duszach, towarzyszącej każdemu w mocy i czynach" (Serafin z Sarowa 76).

${ }^{2}$ Nawiązuje on m.in. do miejsca (bemy) prezbiterów w absydzie ołtarzowej świątyń bizantyńskich (syryjskich). Synthronon, z którego świat usłyszy Dobrą Nowinę, jest miejscem liturgii Słowa (w ikonografii zesłania Ducha Świętego jest to miejsce pierwszego głoszenia Ewangelii światu). Pozostałość po bemie stanowi usytuowany przed ikonostasem ambon (Janocha, Ukraińskie i białoruskie ikony... 403-404).

${ }^{3}$ Paweł Kiejkowski interpretuje obecność Pawła, Marka i Łukasza w tym wydarzeniu jako symbol otwartości Kolegium Apostolskiego na całe ciało Kościoła, którego dopełnieniem jest Kościół chwalebny (Kiejkowski 193).

${ }^{4}$ Mowa tutaj o Chrystusowej paruzji. 


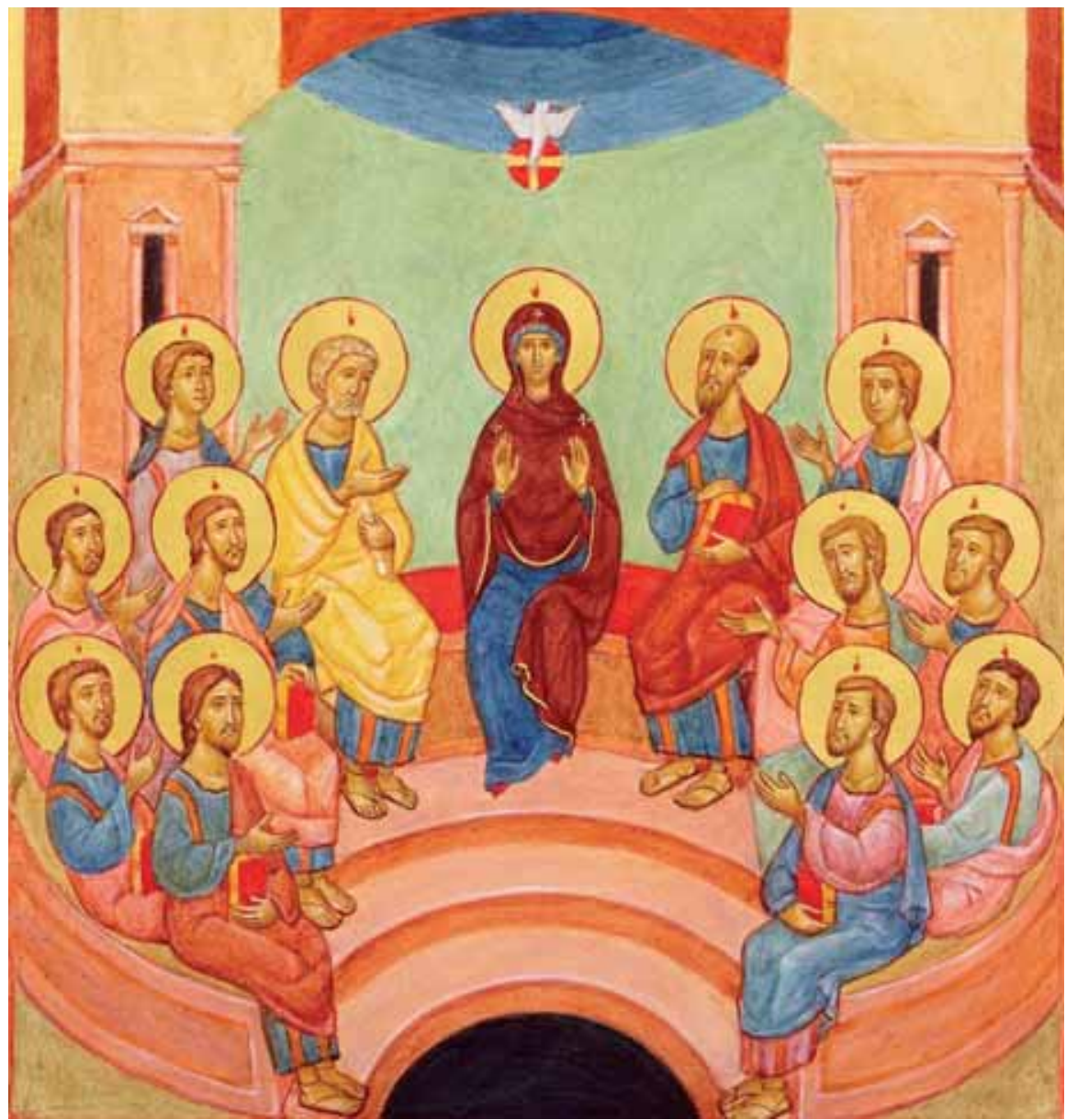

Ilustracja 2. Dostęp 25 sierpnia $2018<$ http://pddm.pl/wp-content/uploads/2014/10/ KRZYZ_9_Zeslanie_Ducha-B.jpg>

ska 92; Еремина 216) (por. il. 2) ${ }^{5}$. Owo puste, centralne miejsce przeznaczone jest dla niebiańskiego tronu (hetojmazja, z gr. przygotowanie, gotowość), który symbolizuje paruzję i panowanie Jezusa Chrystusa, a także Jego majestat i sprawiedliwy sąd (por. miniatura z Psatterza Chludowskiego) (Smykowska 30-31; Paprocki 30-34). Na temat obecności Matki Bożej w Wieczerniku pod-

${ }^{5}$ Za przykład niech posłuży ikona z Kobła Starego (Polska), z drugiej połowy XVII w. Poza klasycznymi motywami ukazuje ona miecz u stóp Maryi, ale być może jako atrybut znajdującego się w pobliżu św. Pawła, oraz postać Boga z trzema obliczami (Trinitas Trifrons) (Janocha, Ikony w Polsce 218). 
czas pięćdziesiątnicy teksty liturgiczne kręgu bizantyńskiego milczą. Jej nieobecność w tym misterium wyjaśnia się posiadaniem przez Nią pełni Ducha Świętego i całkowitym Jej z Nim zjednoczeniem (Janocha, Ukraińskie i białoruskie ikony... 403; Cyrek 68).

\section{Adresat apostolskiej misji}

Adresat tej misji wyobrażany jest w wypełnionej ciemnością arkadzie (dolna część ikony), poniżej synthrononu, na osi pustego, widocznego między Piotrem i Pawłem miejsca. Począwszy od X w., był nim, prezentowany w półfigurze, Król-Starzec, który personifikował Kosmos, w znaczeniu: całe stworzenie (por. Passarelli 290) (por. il. 3). Odziany w królewskie szaty, z koroną na skroniach, dzierży na rozłożonych rękach białe płótno $\mathrm{z}$ dwunastoma zwojami (Dionizjusz 128). Jednak nie tylko ta postać wyobrażana była i jest na owej ikonie jako adresat Ewangelii.

Zamiast Króla-Starca widniał wcześniej prarodzic Adam; przedstawiani byli także poganie (Іванчо 416). Owi poganie, którzy pojawili się w arkadzie w ikonografii zesłania Ducha Świętego jeszcze przed Królem-Starcem, to reprezentanci rozmaitych ludów oczekujących na pięćdziesiątnicę i Ewangelię, którą to Dobrą Nowinę mieli najpierw usłyszeć od apostołów. Stąd w pierwszym tysiącleciu wyobrażana jest poniżej Dwunastu grupa uzbrojonych lub egzotycznie odzianych przedstawicieli rozmaitych, pogańskich ludów i języków, tworzących wspólnie, zdaniem Henryka Paprockiego, Kosmos (Paprocki 34). Obecnie poganie w scenie zesłania Ducha Świętego widnieją np. na współczesnym fresku w białostockiej cerkwi pw. Ducha Świętego.

Wracając do obecności Króla-Starca w ikonografii Pięćdziesiątnicy, należy dopowiedzieć, że ciemna arkada z personifikacją Kosmosu zaczyna zanikać w nowożytności, a na ikonach z XVII i XVIII w. jest często pusta lub nie ma jej wcale (por. Janocha, Ikony w Polsce 220; Janocha, Ukraińskie i białoruskie ikony 409). Warto też uściślić, że konsekwentnie umieszcza się Króla-Starca do XVII w., np. na rodzimych ikonach Pięćdziesiątnicy, lecz nie zawsze w arkadzie.

Przyjrzyjmy się samej personifikacji, która uosabia świat oczekujący na Ewangelię, a do tego momentu pogrążony w mroku i niewiedzy. Jest to świat zniewolony, dlatego Król-Starzec był czasem przedstawiany za kratą (Janocha, Ikony w Polsce 220; Klauza 257; por. Evdokimov, Sztuka ikony, teologia piękna 281). Do chwili odkupienia bowiem Kosmos tkwił w niewoli Szatana. Niewolę tę w niecodzienny sposób uwydatnia np. rodzima ikona z Kobła Starego, datowana na drugą połowę XVII w., ponieważ ukazuje ona wspomnianą personifikację jako wyposażoną w diabelskie rogi (Janocha, Ikony w Polsce 220). 


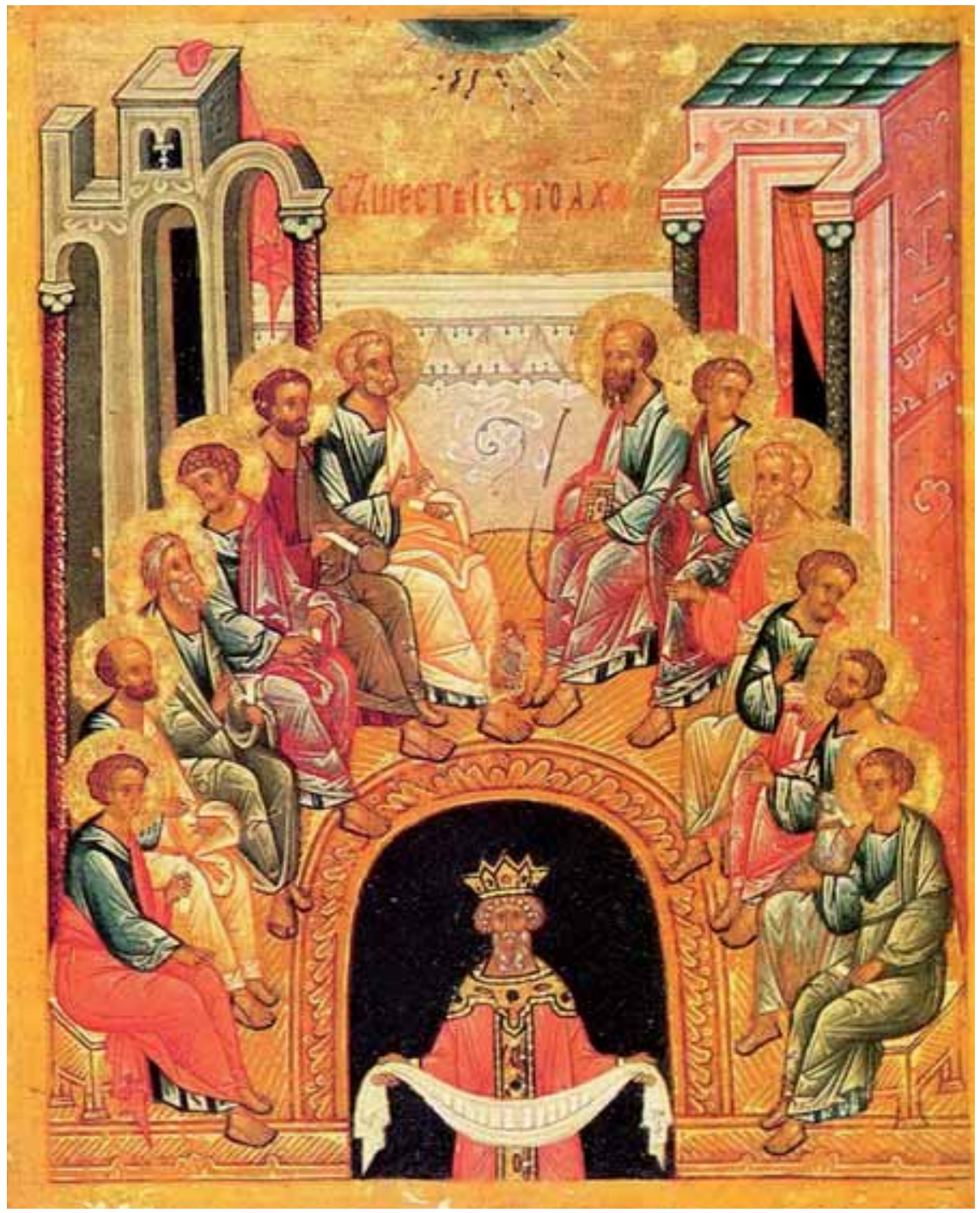

Ilustracja 3. Dostęp 25 sierpnia $2018<$ https:/www.karmel.pl/ikona-zeslania-ducha-swietego/>

W owym Królu-Starcu dostrzega się także bizantyńskiego basileusa jako formalnego władcę pogańskich ludów i narodów, których miejsce zajął w ikonografii Pięćdziesiątnicy. Może on również ewokować, dzięki swojemu ikonograficznemu podobieństwu, starotestamentowego króla Dawida jako reprezentanta przedstawicieli proroków i sprawiedliwych, którzy pragnęli ujrzeć Mesjasza (Mt 13,17; por. Passarelli 291). Niekiedy też Króla-Starca utożsamia 
się z prorokiem Joelem (o czym świadczy nimb personifikacji Kosmosu), nawiązując do urzeczywistnionej w Wieczerniku jego zapowiedzi wylania Ducha Świętego (J1 3,1; Janocha, Ukraińskie i białoruskie ikony... 405). Jednakże najczęściej w postaci Króla-Starca widzi się właśnie personifikację całego stworzenia. Jednym z prototypów tej personifikacji jest antyczny Uranos, brodaty bóg niebios (przedstawiany w półpostaci i z draperią dzierżoną przezeń ponad głową), który włączony został w ikonografię cesarskiej dominacji suwerena ${ }^{6}$.

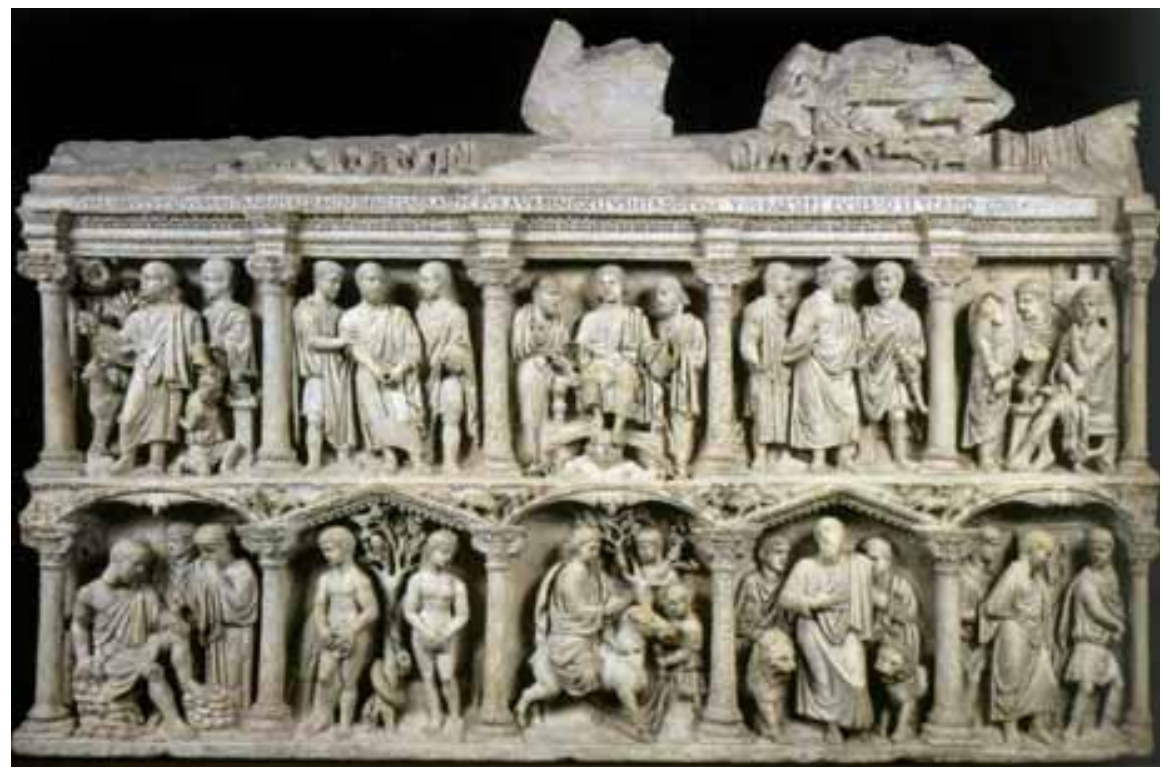

Ilustracja 4. Sarkofag Juniusza Bassusa. Dostęp 25 sierpnia $2018<$ http://artbiblique. hautetfort.com/media/00/01/1330447912.jpg>

Król-Starzec trzyma na rękach płótno, najczęściej z dwunastoma zwojami. Owe zwoje symbolizują nie tylko głoszenie Ewangelii przez apostołów, ale również wypełniające się w konkretnym momencie proroctwa; są zatem symbolem apostolskiej nauki i powszechnej obietnicy zbawienia (Janocha, Ikony w Polsce 220; Іванчо 416; Evdokimov, Sztuka ikony, teologia piękna 281; Klauza 256). Henryk Paprocki dopowiada: „za pośrednictwem Apostołów Ducha Świętego otrzymuje oczekujący zbawienia 'Kosmos'. Kościół jest

\footnotetext{
${ }^{6}$ Uranos widnieje chociażby w rzeźbiarskiej dekoracji wczesnochrześcijańskiego sarkofagu Juniusza Bassusa. Owym suwerenem jest tutaj Jezus Chrystus (przedstawiony po raz pierwszy jako Pantokrator vel Kosmokrator) (il. 4).
} 
bowiem oświeceniem świata, któremu Duch Święty jest dany jako zadatek [...], zadanie, talent do wykorzystania" (Paprocki 31).

Nie bez znaczenia jest także lśniąca biel płótna. Sugeruje ona światło Ewangelii (Іванчо 417). Według Karola Klauzy owa biel manifestuje „syntezę wszystkich barw, a więc wszystkich wyrażanych kolorami cnót i elementów doktryny ewangelicznej” (Klauza 257), kontrastując z czernią braku, śmierci i niewiedzy (Klauza 257). Nadto biel ta zaprasza całe stworzenie do uczestniczenia w Bożej chwale, której atrybutem jest światłość (por. Evdokimov, Poznanie Boga w tradycji wschodniej... 127).

Niemniej jednak nie zawsze Król-Starzec ma na płótnie dwanaście zwojów. Zamiast nich mogą się na nim znajdować, ale rzadziej, maleńkie główki, które oznaczają dusze ludzi oczekujących na światło Ducha Świętego (Janocha, Ukrainskie i białoruskie ikony... 405). Ducha Świętego, który oczyszcza i uświęca, a w konsekwencji przemienia stworzoną rzeczywistość, pragnącą powrócić do swojej duchowej natury i dlatego radującą się z powodu Pięćdziesiątnicy (por. Špidlík 253). Tę przemianę można dostrzec jedynie oczami wiary, ponieważ „Kosmos nie zmienia się w swej egzystencji empirycznej” (Meyendorff 159).

Duch Święty w ikonografii pięćdziesiątnicy zstępuje na Kościół, przy czym Włodzimierz N. Łosski wyjaśnia: „Pięćdziesiątnica nie jest 'dalszym ciągiem' Wcielenia, a jego następstwem, skutkiem: stworzenie stało się zdolne do otrzymania Ducha Świętego, więc zstępuje On na świat, wypełniając swą obecnością Kościół - odkupiony i obmyty z grzechu krwią Chrystusową" (Łosski 152-153)7 . Ukazująca pięćdziesiątnicę ikona zawiera ponadto w sobie, według Pawła Evdokimova, ideę dominacji nieograniczonej przestrzeni eklezjalnej nad całą stworzoną rzeczywistością (Evdokimov, Sztuka ikony, teologia piękna 281). Skutkiem tej dominacji ma być Kosmos ,idealny, ogarnięty Bożym ogniem [...]” (Evdokimov, Sztuka ikony, teologia piękna 281).

To właśnie dzięki owej prawdzie los Kosmosu personifikowanego przez Króla-Starca, „więźnia ciemności” (Tradigo 152), wbrew pesymizmowi rodzącemu się ze zniewolenia, przeniknięty jest nadzieją na wyzwolenie z mroku zła. Karol Klauza pisze: „Czerń tła to symbol cienia śmierci, a zarazem wyczekiwania na spełnienie obietnicy wyzwolenia z mroków niewiedzy i wyjścia do blasku światła, towarzyszącego apostołom” (Klauza 256-257). O tej nadziei wspomina również Paweł Evdokimov, gdy stwierdza, że wyobra-

${ }^{7}$ „Świątynia, w której zasiadają Apostołowie jest rozumiana jako nowy świat i nowe królestwo. Jest to zarazem ideał kosmiczny, który powinien wyprowadzić z niewoli rzeczywisty 'Kosmos'. Aby nastąpiło wyzwolenie z niewoli, kosmos powinien stać się świątynią. Świątynia winna włączyć w siebie nie tylko nowe niebo, ale i nową ziemię. Tego typu kosmiczny przewrót może dokonać jedynie potęga, która jest przedstawiona na ikonie Pięćdziesiątnicy pod postacią języków ognia" (Paprocki 35). 
żony na ikonie Kosmos „pokazuje swoimi wyciągniętymi dłońmi, że nawet piekielna rozpacz została dotknięta nadzieją będącą jej odwiecznym jądrem [...]" (Evdokimov, Sztuka ikony, teologia piękna 281).

Ikona Zesłanie Ducha Świętego ukazuje ponadto kontrast między światłem i mrokiem, kontrast dwóch rzeczywistości, które i są, i nie są oddalone od siebie: „nowego nieba i nowej ziemi”, tudzież świata pogrążonego w niewoli zła. Ten „malarski kontrast między niebiańskim blaskiem a mrokiem otchłani oddaje duchowy dramat Boga i człowieka, objawiony światu w tajemnicy Wcielenia i Paschy" (Janocha, Ukraińskie i białoruskie ikony... 405. 417).

Nie tylko ikona Zestanie Ducha Świętego, ale każda inna „ukazuje wizję przemienionego kosmosu" (por. Bułgakow 138). Przemiana stworzonej rzeczywistości dokonuje się w mocy Ducha Świętego, którego Jan Paweł Strumiłowski nazywa m.in. „źródłem promiennego blasku Boga jaśniejącego w stworzeniu" (Strumiłowski 106), przemieniającym Kosmos w Boże piękno (Hryniewicz 155).

\section{THE MISSIONAL DIMENSION OF THE ICON OF THE DESCENT OF THE HOLY SPIRIT}

\section{A B S T R A C T}

The icon of The Descent of the Holy Spirit includes a mission message. The origins of the iconography of this mystery date back to the 6th century. The icon of Pentecost depicts the apostles, and an empty place between them, destined for the coming again of Jesus Christ. Adam was presented below, and then the pagans as representatives of the peoples and nations to whom the apostles are sent. Later in this place is presented Old King as a personification of the Cosmos, that is here a personification of all creatures. The apostles, as the first missionaries, will proclaim the Gospel to this Cosmos.

${ }^{8}$ Dalej Michał Janocha stwierdza: „Ikona Pięćdziesiątnicy objawia paradoksalną naturę świata. Ten świat, przed którym pragnęli uciec przerażeni po śmierci Pana apostołowie, ten świat, przed którym [...] w przestrachu zamknęli drzwi Wieczernika, który znalazł się niejako na zewnątrz nich, na ikonie umieszczony jest wewnątrz, dokładnie w samym środku. To do niego i dla niego zstępuje Duch Pocieszyciel [...] ten sam Duch, obiecany Pocieszyciel, za pośrednictwem apostołów, Kościoła, posłany zostaje do wszystkich ludzi wszystkich czasów pogrążonych w ciemnej otchłani niewiedzy i grzechu. I oto dumny świat okazuje się zamkniętym w lochu starcem, zamknięty Wieczernik - otwartym, wszechogarniającym domem, a Pięćdziesiątnica - rzeczywistością kosmiczną, przekraczającą ramy jednostkowego wydarzenia historycznego, sakramentem miłości” (Janocha, Ukraińskie i białoruskie ikony... 417). 
Keywords: icon; Descent of the Holy Spirit; mission; symbolism; iconography

Slowa kluczowe: ikona; Zesłanie Ducha Świętego; misja; symbolika; ikonografia

\section{BIBLIOGRAFIA}

Bator, Zofia. „Maryja w ikonie Zesłania Ducha Świętego a jedność chrześcijan.” Salvatoris Mater 10. 2 (2008): 247-268.

Bulas, M. Ryszarda. „Palestyńskie ampułki ze zbiorów Monza - Bobbio. Program ikonograficzny.” Vox Patrum 35. 64 (2015): 93-103.

Bułgakow, Sergiusz. Ikona i kult ikony. [Zarys dogmatyczny]. Tłum. Henryk Paprocki. Bydgoszcz: Homini, 2002.

Cyrek, Olga. „Przedstawienia Ducha Świętego na ikonach bizantyjskich i ruskich. Kanon ikonograficzny a dogmat teologiczny." Analecta Cracoviensia 44 (2012): 57-71.

Dionizjusz z Furny. Hermeneja, czyli objaśnienie sztuki malarskiej. Tłum. Ireneusz Kania. Kraków: Wydawnictwo UJ, 2003.

Evdokimov, Paul. Duch Święty w tradycji prawosławnej. Poznań: „W drodze”, 2012.

Evdokimov, Paul. Poznanie Boga w tradycji wschodniej. [Patrystyka, liturgia, ikonografia]. Tłum. Alina Liduchowska. Kraków: Wydawnictwo M, 1996.

Evdokimov, Paul. Prawosławie. Tłum. Jerzy Klinger. Warszawa: IW PAX, 2003.

Evdokimov, Paul. Sztuka ikony, teologia piękna. Tłum. Maria Żurowska. Warszawa: Promic, 1999. Hryniewicz, Wacław. „Piękno i zbawienie. [Kilka refleksji nad eschatologią ikony].” Obraz i kult. [Materiały z Konferencji ,Obraz i kult” KUL - Lublin 6-8 października 1999]. Red. Małgorzata Urszula Mazurczak; Jowita Patyra. Lublin: Wydawnictwo KUL, 2002. 143-171.

Іванчо, Іштван. Ікона і літургіа. Львів: Свічабо, 2009.

Janocha, Michał. Ikony w Polsce. [Od średniowiecza do współczesności]. Warszawa: Arkady, 2008.

Janocha, Michał. Ukraińskie i białoruskie ikony świateczne $w$ dawnej Rzeczypospolitej. [Problem kanonu]. Warszawa: Neriton, 2001.

Kiejkowski, Paweł. „Chrystus wielkim Prekursorem Ducha Świętego. [Pneumatologiczny rys trynitarnej ekonomii zbawienia w teologii Paula Evdokimova]." Studia Gnesnensia t. XXVIII (2014): 187-203.

Klauza, Karol. Teokalia, piękno Boga. [Prolegomena do estetyki dogmatycznej]. Lublin: Wydawnictwo KUL, 2008.

Leśniewski, Krzysztof. „Wpływ obrazów Kościoła na trynitarną wrażliwość chrześcijan. [Dokument „Ku wspólnej wizji Kościoła” w świetle eklezjologii prawosławnej].” Studia Oecumenica 14 (2014): 109-123.

Łosski, N. Włodzimierz. Teologia mistyczna Kościoła wschodniego. Tłum. Izabela Brzeska. Kraków: Wydawnictwo UJ, 2007.

Metropolita, Sawa (Hrycuniak, Michał). Baczyński, Andrzej. „Duch Święty w dziele uświęcenia człowieka." Rocznik Teologiczny LIX. 3 (2017): 373-404.

Meyendorff, John. Teologia bizantyjska. [Historia i doktryna]. Thum. Jerzy Prokopiuk. Kraków: Wydawnictwo UJ, 2007.

Paprocki, Henryk. Obietnica Ojca. Doświadczenie Ducha w Kościele Prawosławnym. Bydgoszcz: Homini, 2001.

Passarelli, Gaetano. Non solo colore. [Icone e Feste della tradizione bizantina]. Roma: Nova Millennium Romae, 2013.

Serafin z Sarowa. Ogień Ducha Świętego. Tłum. Henryk Paprocki. Kraków: Wydawnictwo Esprit, 2018.

Smykowska, Elżbieta. Ikona. Mały słownik. Warszawa: Verbinum, 2002. 
Špidlík, Tomáś. Myśl rosyjska. [Inna wizja człowieka]. Tłum. Janina Dembska. Warszawa: Wydawnictwo Księży Marianów, 2000.

Strumiłowski, Paweł Jan. Piękno zbawi świat? Kraków: WAM, 2016.

Tradigo, Alfredo. Ikony i święci prawosławni. Tłum. Ewa Maciszewska. Warszawa: Arkady, 2011.

Еремина, С. Татьяна. Мир русских икон. [Историа, предания]. Москва: Терра - Книжный Клуб, 2002.

JUSTYNA SPrutTa, dr, teolog, historyk sztuki, filolog. Absolwentka KUL, UKSW i UAM. Wykładowca na Wydziale Teologicznym UAM w Poznaniu. Współpracuje z portalem www.misyjne.pl i dwutygodnikiem diecezji kaliskiej „Opiekun”. Autorka ponad stu artykułów naukowych, w tym obcojęzycznych, oraz książki Sztuka i wychowanie. Obecnie przygotowuje książkę Teatr $i$ wychowanie. Członkini Polskiego Instytutu Studiów nad Sztuką Świata i Poznańskiego Towarzystwa Przyjaciół Nauk. 